\title{
Identification of novel ER-alpha target genes in breast cancer cells: Gene- and cell-selective co-regulator recruitment at target promoters determines the response to 17beta-estradiol and tamoxifen
}

Citation for published version (APA):

Romano, A., Michiel Adriaens, M. E., Kuenen, S., Delvoux, B., Dunselman, G., Evelo, C., \& Groothuis, P. (2010). Identification of novel ER-alpha target genes in breast cancer cells: Gene- and cell-selective coregulator recruitment at target promoters determines the response to 17beta-estradiol and tamoxifen. Molecular and Cellular Endocrinology, 314(1), 90-100. https://doi.org/10.1016/j.mce.2009.08.008

Document status and date:

Published: 15/01/2010

DOI:

10.1016/j.mce.2009.08.008

Document Version:

Publisher's PDF, also known as Version of record

Document license:

Taverne

Please check the document version of this publication:

- A submitted manuscript is the version of the article upon submission and before peer-review. There can be important differences between the submitted version and the official published version of record. People interested in the research are advised to contact the author for the final version of the publication, or visit the DOI to the publisher's website.

- The final author version and the galley proof are versions of the publication after peer review.

- The final published version features the final layout of the paper including the volume, issue and page numbers.

Link to publication

\footnotetext{
General rights rights.

- You may freely distribute the URL identifying the publication in the public portal. please follow below link for the End User Agreement:

www.umlib.nl/taverne-license

Take down policy

If you believe that this document breaches copyright please contact us at:

repository@maastrichtuniversity.nl

providing details and we will investigate your claim.
}

Copyright and moral rights for the publications made accessible in the public portal are retained by the authors and/or other copyright owners and it is a condition of accessing publications that users recognise and abide by the legal requirements associated with these

- Users may download and print one copy of any publication from the public portal for the purpose of private study or research.

- You may not further distribute the material or use it for any profit-making activity or commercial gain

If the publication is distributed under the terms of Article 25fa of the Dutch Copyright Act, indicated by the "Taverne" license above,

Download date: 26 Apr. 2023 


\title{
Identification of novel ER- $\alpha$ target genes in breast cancer cells: Gene- and cell-selective co-regulator recruitment at target promoters determines the response to $17 \beta$-estradiol and tamoxifen
}

\author{
Andrea Romano $^{\mathrm{a}, \mathrm{b}, *}$, Michiel Adriaens ${ }^{\mathrm{c}}$, Sabine Kuenen ${ }^{\mathrm{a}, \mathrm{b}}$, Bert Delvoux ${ }^{\mathrm{a}, \mathrm{b}}$, \\ Gerard Dunselman ${ }^{\mathrm{a}, \mathrm{b}}$, Chris Evelo $^{\mathrm{c}}$, Patrick Groothuis $\mathrm{s}^{\mathrm{a}, \mathrm{b}, 1}$ \\ ${ }^{\text {a }}$ GROW, School for Oncology and Developmental Biology, Maastricht University Medical Centre, 6202 AZ Maastricht, The Netherlands \\ ${ }^{\mathrm{b}}$ Department of Obstetrics and Gynaecology, Maastricht University Medical Centre, 6202 AZ Maastricht, The Netherlands \\ c Department of Bioinformatics - BiGCaT, Maastricht University Medical Centre, 6202 AZ Maastricht, The Netherlands
}

\section{A R T I C L E I N F O}

\section{Article history:}

Received 15 April 2009

Received in revised form 12 August 2009

Accepted 12 August 2009

\section{Keywords:}

$17 \beta$-Estradiol

Estrogen receptor- $\alpha$

Co-activators

Co-repressors

Tamoxifen

\begin{abstract}
A B S T R A C T
Tamoxifen and $17 \beta$-estradiol are capable of up-regulating the expression of some genes and downregulate the expression of others simultaneously in the same cell. In addition, tamoxifen shows distinct transcriptional activities in different target tissues.

To elucidate whether these events are determined by differences in the recruitment of co-regulators by activated estrogen receptor- $\alpha$ (ER- $\alpha)$ at target promoters, we applied chromatin immunoprecipitation (ChIP) with promoter microarray hybridisation in breast cancer T47D cells and identified 904 ER- $\alpha$ targets genome-wide. On a selection of newly identified targets, we show that $17 \beta$-estradiol and tamoxifen stimulated up- or down-regulation of transcription correlates with the selective recruitment of co-activators or co-repressors, respectively. This is shown for both breast (T47D) and endometrial carcinoma cells (ECC1). Moreover, differential co-regulator recruitment also explains that tamoxifen regulates a number of genes in opposite direction in breast and endometrial cancer cells. Over-expression of co-activator SRC-1 or co-repressor SMRT is sufficient to alter the transcriptional action of tamoxifen on a number of targets. Our findings support the notion that recruitment of co-regulator at target gene promoters and their expression levels determine the effect of ER- $\alpha$ on gene expression to a large extent.
\end{abstract}

(c) 2009 Elsevier Ireland Ltd. All rights reserved.

\section{Introduction}

Upon ligand activation, estrogen receptor- $\alpha$ (ER- $\alpha)$ binds to the promoters of responsive genes, interacting directly with estrogen response elements (EREs) or indirectly via associations with other transcription factors (reviewed in: Lonard and O'Malley, 2007). Numerous mechanisms participate in the fine-tuning of estrogen regulatory actions in target cells. These mechanisms allow estrogens and selective estrogen receptor modulators (SERMs) to exert opposite transcriptional actions on different genes in the same cell type, or to act as agonists in one cell type and as antagonists in another cell type. However, they may also be responsible for the unwanted side effects that have been observed during the use of

* Corresponding author at: Department of Obstetrics and Gynaecology, Maastricht University Medical Centre, P. Debyelaan 25, 6202 AZ Maastricht, The Netherlands. Tel.: +31 43 3881286/3881352; fax: +31 433874765 .

E-mail addresses: a.romano@og.unimaas.nl, a.romano@maastrichtuniversity.nl (A. Romano).

${ }^{1}$ Present address: Department of Pharmacology, Schering-Plough Corporation, Molenstraat 110, 5342 CC Oss, The Netherlands. these compounds in medical treatments. The SERM tamoxifen, for instance, acts as an ER- $\alpha$ antagonist in breast cancer cells (Conzen, 2008; Riggs and Hartmann, 2003), but it is a partial agonist in the endometrium and increases the incidence of endometrial hyperplasia and cancer (Gielen et al., 2005; Shang, 2006). In addition, the same mechanisms may play a role in the resistance to tamoxifen of breast tumours (Conzen, 2008; Lonard et al., 2007) and in the patient-dependent therapeutic efficacy of tamoxifen for the treatment of ovarian cancer (Perez-Gracia and Carrasco, 2002).

There is increasing evidence that the gene- and cell-specific actions of estrogens depend largely on the presence of coregulators. These proteins either bridge the ER- $\alpha$ /target promotercomplex with the transcriptional machinery (co-activators such as CBP, p300, SRC family) or impair it (co-repressors; SMRT, NCoR; Carroll and Brown, 2006; Lonard and O'Malley, 2007). Several recent studies have indicated that the agonistic or antagonistic action of a SERM is determined by the cellular availability of coregulators in different cell types. For instance, the agonistic action of tamoxifen in endometrial cancer cells is the consequence of high expression of the co-activator SRC-1 (Shang and Brown, 2002). In breast cancer cells, down-regulation of co-repressor NCoR turns 
tamoxifen into an inducer of proliferation and over-expression of co-activator SRC-3 (AIB1) is predictive of resistance to tamoxifen in breast cancer patients and is associated with malignancies in the endometrium (Balmer et al., 2006; Conzen, 2008; Lonard et al., 2007).

Despite these evidences, the direct effect of co-regulators on ER- $\alpha$-controlled gene transcription in distinct cell types has been demonstrated for a limited number of targets only (Shang and Brown, 2002; Shang et al., 2000; Stossi et al., 2006) or by means of reporter gene assays (Peterson et al., 2007; Smith et al., 1997). In addition, it remains difficult to understand how estrogens induce the expression of specific genes and repress others in the same cell type (Bourdeau et al., 2008; Carroll et al., 2006; Hodges et al., 2003; Kwon et al., 2007; Lin et al., 2004, 2007a,b; Groothuis et al., 2007).

In the present study, we aimed at examining whether differential co-regulator recruitment (i) determines different transcriptional actions of one ligand on distinct target genes in the same cell type and (ii) determines the opposite transcriptional regulation of the same genes in different cell types treated with the same ligand. To this end, we applied chromatin immunoprecipitation (ChIP) together with promoter DNA array hybridisation (ChIP-chip) and identified 904 ER- $\alpha$ target promoters in T47D breast cancer cells. On a selection of newly identified target genes, we show that the transcriptional stimulatory or inhibitory effects of $17 \beta$-estradiol or $\mathrm{OH}$-tamoxifen, the active metabolite of tamoxifen, closely correlate with the recruitment of co-activators or co-repressors, respectively. Moreover, recruitment of distinct co-regulators correlates with the opposite transcriptional responses observed in T47D and endometrial cancer cells (ECC1). To further support this notion, we show that over-expression of co-activator SRC-1 or co-repressor SMRT is sufficient to change or to invert $\mathrm{OH}$-tamoxifen response, irrespective to the cell context.

\section{Materials and methods}

\subsection{Cell lines and culture}

The human breast cancer cell line T47D and human endometrial cancer cell line ECC1 were purchased from the American Type Culture Collection (ATCC; Rockville, MD, USA) and maintained as described (Romano et al., 2007). For all experiments involving hormonal stimulation, cells were cultured for five days prior to, and during the experiment in RPMI without phenol-red (Invitrogen, Life Technologies, Inc., Carlsbad, CA) supplemented with 5\% hormone-stripped serum (c.c.pro $\mathrm{GmbH}$, Neustadt, Germany).

\subsection{Steroid hormones}

$17 \beta$-estradiol and $\mathrm{OH}$-tamoxifen were purchased from Sigma-Aldrich Chemie BV (Zwijndrecht, The Netherlands). ICI-164384 was a gift from Schering-Plough(Oss, The Netherlands).

\subsection{RNA extraction and cDNA synthesis}

RNA was isolated using the Trizol reagent (Invitrogen, Life Technologies, Inc. Carlsbad, CA) as recommended by the manufacturer. Complementary DNA (cDNA) was synthesised using the M-MLV reverse transcriptase (Invitrogen, Life Technologies, Inc., Carlsbad, CA) as described earlier (Romano et al., 2007).

\subsection{Oligonucleotides}

Oligonucleotides used for linear-amplification of immunoprecipitated chromatin prior to ChIP-chip and used for PCR were purchased from MWG-Biotech AG (Ebersberg, Germany) and are listed in Supplemental Table S-III.

\section{5. $P C R$ and real-time $P C R(R T-P C R)$}

PCR was performed with the Taq DNA polymerase (Fermentas GMBH, St LeonRot, Germany) as recommended by the manufacturer. Semi-quantitative PCR was performed by stopping PCR reactions every three cycles and by evaluation of band intensity on an agarose gel. RT-PCR was performed using the Syber-green ABGene system (ABGene Limited, Epsom, United Kingdom), as recommended by the manufacturer and the BioRad MylQ apparatus.

\subsection{Chromatin immunoprecipitation}

ChIP was performed as described elsewhere (Romano et al., 2007). Briefly, T47D or ECC1 cells were grown to $80 \%$ confluence $\left(165-\mathrm{cm}^{2}\right.$ culture flasks) treated with vehicle only (ethanol) or with ligand for $50 \mathrm{~min}$, fixed ( $1 \%$ formaldehyde, $10 \mathrm{~min}$ ) and scraped in $1 \mathrm{ml}$ of cold PBS supplemented with Complete ${ }^{\mathrm{TM}}$ protease inhibitor (Roche, Mannheim, Germany). After cell lysis, nuclei were pelleted, lysed and chromatin was sonicated. Chromatin-protein complexes were immunoprecipitated (IP) with protein-G/A magnetic beads (Dynal, Invitrogen Life Technologies, Inc., Carlsbad, CA) and $2 \mu \mathrm{g}$ of specific antibodies: HC-20 against ER- $\alpha, \mathrm{H}-224$ against RNA-Pol-II, C-20, N-15 and A-22 against co-activators SRC-1, p300 and CBP, and antibodies sc1609 and H-300 against co-repressors NCoR and SMRT (Santa Cruz Biotechnology, CA, USA). After IP, bead washing and reverse crosslinking, DNA was purified using the Qiaquick reaction clean-up kit (Qiagen $\mathrm{GmbH}$, Hilden, Germany). Binding of the RNA-Pol-II to the GAPDH promoter was used as positive control of the ChIP procedure and it was assessed using primers ChIP-positive (Supplemental Table S-III). ER- $\alpha$ binding to the TFF1 promoter was used as a positive control for ChIP with the ER- $\alpha$ antibody and it was assessed using primers indicated in Supplemental Table S-III. ChIP PCR signals were normalised with an unspecific negative control, using primers ChIP-negative (Supplemental Table S-III) that flank the cytogenetic location 12 p13.3 where no transcription factors bind. All additional primers used to assess ER- $\alpha$ and co-regulatory protein binding are listed in Supplemental Table S-III.

\subsection{ChIP-chip}

ChIP in T47D cells using the ER- $\alpha$ antibody was performed as described above. Successful ChIP was confirmed by assessing ER- $\alpha$ binding to the promoter of the estrogen responsive gene TFF1. Isolated DNA fragments were subsequently subjected to a linear-amplification as follows: (a) $7.5 \mu$ l of DNA were denatured, amplified with $1.5 \mathrm{U}$ of Sequenase ${ }^{\mathrm{TM}} \mathrm{T7}$ DNA-polymerase (Invitrogen, Life Technologies, Inc., Carlsbad, CA) using primer LA-0 (Supplemental Table S-III) in the recommended buffer ( $1 \mathrm{X}$ ) for $8 \mathrm{~min}$ at $37^{\circ} \mathrm{C}$. This step was repeated once. (b) $15 \mu \mathrm{l}$ of this reaction were amplified by Taq polymerase (Fermentas GMBH, St Leon-Rot, Germany) using primer LA-1 (Supplemental Table S-III) in $0.1 \mathrm{mM}$ dNTPs, 1X recommended buffer, $1.5 \mathrm{mM} \mathrm{MgCl}_{2}$ in $100 \mu \mathrm{l}$ final volume. Aliquots $(5 \mu \mathrm{l})$ were taken at $25,30,35,40$ cycles to determine the number of cycles necessary to enter the exponential phase (which was determined based on the intensity of the smearedDNA visualised on an agarose gel). A second round of amplification using the Taq polymerase was performed. Amplified DNA was purified using the Qiaquick reaction clean-up kit (Qiagen GmbH, Hilden, Germany). Enrichment of the TFF1 promoter was confirmed at intermediate steps of the amplification and at the end of the amplification (Fig. 1A). This quality control guaranteed that the amplification of signals in the ChIP-DNA did not reach saturation and therefore did not result in loss of enrichment of target promoters.

Samples were generated from three independent experiments (T1, T2 and T3). In each experiment, cells were treated with $17 \beta$-estradiol or vehicle for $50 \mathrm{~min}$. In addition, a reference pool $(\mathrm{P})$ was created by pooling equal amounts of the amplified DNA from the $17 \beta$-estradiol and vehicle-treated samples of T1, T2 and T3. The ChIP-DNA fraction was labelled with Cy-5, while the input-DNA, the DNA purified from fragmented chromatin non-subjected to IP reaction and processed through the same linear-amplification as the ChIP-DNA, was labelled with Cy-3. Labelled ChIPand input-DNA fractions from the eight samples (four treated and four untreated) were subsequently hybridised to the Nimblegen HGS17 genome build promoter microarray containing 1500 bp of promoters from 24,134 human genes. Labelling and hybridisation were performed in-house by Nimblegen (Madison, USA). The promoter regions on the array are covered by 50 - to 75 -mer probes with approximately $100 \mathrm{bp}$ spacing. The log-ratio of $\mathrm{Cy}-5$ and $\mathrm{Cy}-3$ intensities was subsequently calculated to assess enrichment of specific promoters of the ChIP-DNA compared to the input-DNA, suggesting binding of ER- $\alpha$. The hybridisation efficiency of the samples from experiment T3 did not meet the quality criteria and these samples were excluded from further analysis.

\subsection{Statistical analysis}

Two different methods were evaluated for the identification of ER- $\alpha$ targets. Method (i), a within-array analysis, searches for four or more probes in each $1500 \mathrm{bp}$ promoter whose signals are above a specified cut-off value. This analysis was performed using the proprietary software of Nimblegen. Method (ii) is a betweenarray analysis, employing positive (treated replicate samples) and negative controls (vehicle-treated samples) at probe level, which was performed in the statistical programming language R. This latter method is expected to produce a statistically more robust set of potential ER- $\alpha$ targets. First, the log-ratio between ChIP-DNA and inputDNA intensities is calculated separately for each array. Next, all probes are ordered according to genomic location and dichotomised using a threshold around twice the estimated standard deviation of the log-ratio. Probes with log-ratio values above this threshold are designated as positive, those below the threshold negative. Next, for each array, a sliding window of a variable number of base pairs is moved over all probes, calculating a $p$-value for each window with a Yates corrected chi-square test. To determine whether a promoter shows true significant enrichment, the promoter has to contain at least one window that shows significant enrichment in at least two 
(A)

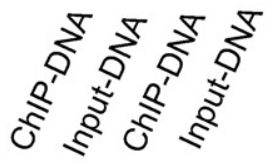

Experiment T1

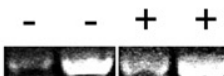

$17 \beta$-estradiol

\section{Experiment T2}

Experiment $\mathrm{T} 3$
(B)

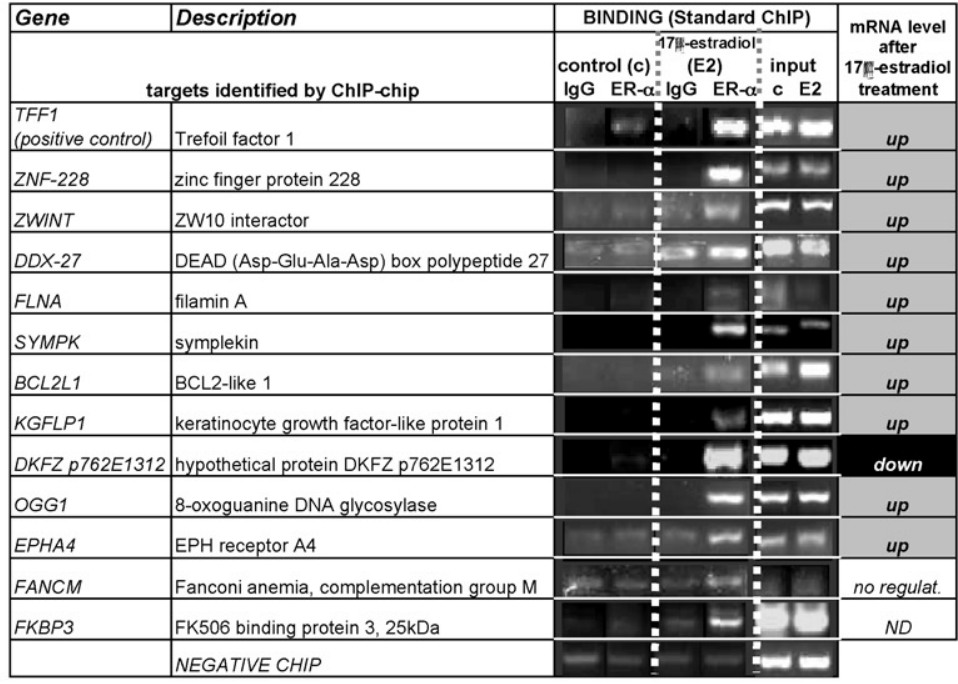

(C) EREs AMONG THE 904 ER- $\alpha$ TARGETS

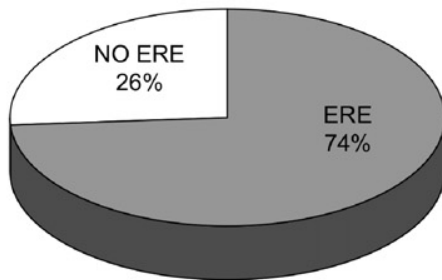

$P<0.0001$

Fig. 1. ChIP-chip: quality control, validation and prevalence of EREs. (A) Prior to ChIP-chip hybridisation, immunoprecipitated (IP) DNA fragments were amplified (linearamplification). As a quality check, binding of ER- $\alpha$ to the TFF1 promoter was confirmed after each amplification round (shown for each experiment at the end of the amplification, just prior to labelling and hybridisation). ChIP-DNA = IP DNA. Input-DNA = non-IP- chromatin amplified similarly to the ChIP-DNA. (B) ER- $\alpha$ targets identified by ChIP-chip and validated by standard ChIP. For all ChIP experiments, cells were treated for $50 \mathrm{~min}$; control = vehicle-treated cells; E2 or $17 \beta$-estradiol: $1 \mathrm{nM}$. IgG =ChIP with non-specific antibodies; ER- $\alpha=$ ChIP with the ER- $\alpha$ antibody. Column on the right: mRNA level of the corresponding gene after $17 \beta$-estradiol ( $1 \mathrm{nM}$ ) induction. $\mathrm{mRNA}$ was assessed (RT-PCR or semi-quantitative PCR-semiQ-PCR) after different periods of hormone stimulation (up to $24 \mathrm{~h}$ ) in triplicate. Results in column signify that the considered mRNA is significantly regulated in the indicated direction ( $p<0.05$ compared to time point zero) at one time point at least (results not shown). ND: not determined. (C) Prevalence of EREs in the promoters of the entire group ( $n=904)$ of ER- $\alpha$ target genes as determined by Genomatix MatInspector (http://www.genomatix.de). Promoters were scanned using a family of ERE consensus matrices (Cartharius et al., 2005).

treated samples (positive controls) and the same window or windows should not show significant enrichment in more than one untreated sample (negative controls). To minimise false positives, an adaptation of the Benjamini and Hochberg method (Benjamini and Hochberg, 1995) is applied to calculate false discovery rates (FDR).

Both methods showed over $50 \%$ consistency when a FDR threshold of $20 \%$ was applied. We compared the list of target genes obtained with the two methods with a list of already known targets (O'Lone et al., 2004). Given that at the same FDR, method (ii) retrieved a larger number of known target promoters when compared to method (i) and considering the greater robustness of a between-array approach, method (ii) was used to generate the list of targets used for further analysis.

To identify our 904 promoters, we combined results using two FDR cut-off points. We first identified a suitable cut-off point able to retrieve as many previously found targets (O'Lone et al., 2004) as possible. Using a FDR cut-off of $20 \%$ we identified most known targets (i.e. CTSD, BRCA, c-Myc, ADORA1, AGT, HSPB1, LCN2) and only few more (TGFA, TERT) were retrieved when cut-off points with lower stringency (FDR cut-offs higher than 20\%) were used. Therefore, 20\% FDR was fixed as the upper limit for the stringency of our statistics. Subsequently, a low stringency (FDR 20\%) was used to identify ER- $\alpha$ targets common in the arrays of the independent experiments (T1 and T2 or T1, T2 and P). A high stringency (FDR 5\%) was used for targets that were common in one of the $\mathrm{T}$ arrays and the $\mathrm{P}$ array, as those are essentially technical replicates.

The promoter regions were scanned for occurrence of EREs using the Genomatix MatInspector software (Cartharius et al., 2005) and the Genomatix transcription factor motif database (www.genomatix.de). We also scanned promoter sequences of a validated sub selection of $\mathrm{ER}-\alpha$ targets for the presence of potential tethering domains for EREs (AP1, NFKB and SP1 binding sites), using the same approach.

\subsection{Cell transfection, luciferase assay and immunocytochemistry}

Plasmids used for transfection were previously described: ERE-TK-luciferase (2X ERE-TK-LUC) containing the estrogen responsive promoter-luciferase reporter (Oehler et al., 2004), was gifted by Prof Schuele. The expression vector for co- activator SRC-1 (Smith et al., 1997) and the co-repressor SMRT (Chen and Evans, 1995) were gifts from Prof O'Malley and Prof Evans, respectively. The SMRT expression plasmid used in these experiments encodes for a truncated form of the human co-repressor SMRT (amino-acids 1032-2517) with a dominant co-repressing action (Peterson et al., 2007). Plasmid pCNDA3.1 (Invitrogen, Life Technologies, Inc., Carlsbad, CA) was used as empty vector (when indicated). All techniques were previously described (Romano et al., 2007). In short, transfection was performed using the jetPEI $^{\mathrm{TM}}$ reagent (Q-Biogene, Heidelberg, Germany) as recommended by the manufacturer. Prior to luciferase assays, cells were cultured in 2 wells of a 12-well plate and were transfected ( $2 \mu \mathrm{g}$ DNA plus $3 \mu \mathrm{l}$ jetPEI ${ }^{\mathrm{TM}}$ per well). Sixteen hours after transfection, cells from the 2 wells were trypsinised, pooled and seeded into 12 wells of a 96-well plate. Eight hours after plating, treatments were applied. Each treatment was performed in triplicate (the number of initially transfected wells was scaled up according to the number of stimulations needed). In case of RNA isolation, cells were transfected in two $25-\mathrm{cm}^{2}$ flasks $\left(10 \mu \mathrm{g}\right.$ DNA plus $15 \mu \mathrm{l} \mathrm{jetPEI}{ }^{\mathrm{TM}}$ per flask) and subsequently cells were pooled and plated in 9 wells of a 12 -well plate. For immunocytofluorescence, cells were cultured on glass cover slips fixed in buffered formaldehyde (4\% paraformaldehyde in PBS), permeabilised with 0.1\% Triton-X-100 in PBS and stained with the following antibodies (as indicated in the figures): goat polyclonal C-20 against co-activator SRC-1 and sc-1609 against co-repressor NCoR (Santa Cruz Biotechnology, CA, USA), followed by anti-goat FITC secondary antibody 705-095-147 (Jackson Immunoresearch/Brunschwig chemie B.V., Amsterdam, The Netherlands); rabbit polyclonal H-300 against co-repressor SMRT (Santa Cruz Biotechnology, CA, USA), followed by anti-rabbit FITC F005401 (DAKO, Glostrup, Denmark). For western blot (Supplemental Figure S-1) ER- $\alpha$ was detected with monoclonal antibody F10 (Santa Cruz Biotechnology, CA, USA), whereas p300 and CBP with rabbit A-22 and N-15 antibodies, respectively (Santa Cruz Biotechnology, CA, USA). Mouse antibody AC-15 (Sigma-Aldrich Chemie BV, Zwijndrecht, The Netherlands) was used to detect $\beta$-actin. HRP-conjugated rabbit anti-mouse-antibodies (DAKO, Glostrup, Denmark) and goat-anti-rabbit-antibodies (Pierce, Aalst, Belgium) and the super signal-R West-Femto kit (Pierce, Aalst, Belgium) were used for primary antibody visualisation. 
Table 1

Number of ER- $\alpha$ binding sites per chromosome.

\begin{tabular}{ll}
\hline Chromosome & Number of sites \\
\hline 1 & 79 \\
2 & 51 \\
3 & 45 \\
4 & 36 \\
5 & 36 \\
6 & 61 \\
7 & 41 \\
8 & 35 \\
9 & 43 \\
10 & 25 \\
11 & 83 \\
12 & 56 \\
13 & 17 \\
14 & 33 \\
15 & 31 \\
16 & 27 \\
17 & 54 \\
18 & 12 \\
19 & 41 \\
20 & 31 \\
21 & 12 \\
22 & 21 \\
$X$ & 34 \\
\hline
\end{tabular}

\subsection{URL}

Nimblegen: www.nimblegen.com; Genomatix transcription factor database: www.genomatix.de.

\section{Results}

\subsection{Identification of genomic binding sites for $E R-\alpha$}

ER- $\alpha$ binding sites in gene promoters were searched genomewide using the estrogen responsive T47D breast cancer cells. Estrogen responsiveness was shown by the expression of ER- $\alpha$, the induction of various known estrogen responsive genes (TFF1, c-Myc, CCND1) and by the induction of cell proliferation by $17 \beta$-estradiol (Supplemental Figures S-1 and S2). T47D cells were incubated with $1 \mathrm{nM} 17 \beta$-estradiol for $50 \mathrm{~min}$, which was shown to result in maximal ER- $\alpha$ binding to the TFF1 promoter (Carroll et al., 2005, 2006; this study, results not shown). After chromatin immunoprecipitation using an ER- $\alpha$ antibody, two rounds of nucleic acid amplification were performed to yield sufficient DNA for hybridisation to the Nimblegen promoter arrays. In order to assure adequate quality of the amplified DNA fragments, enrichment of the TFF1 promoter was confirmed after each amplification round (Fig. 1A). Three independent experiments, each consisting of a $17 \beta$-estradiol and a vehicle-treated sample, were performed (T1, T2 and T3). Given that the hybridisation performance of the T3 samples was poor, data from experiment $\mathrm{T} 3$ were not used for subsequent analyses. An additional sample was included (referred to as the pool, P) created by combining equal amounts of amplified DNA material from $\mathrm{T} 1, \mathrm{~T} 2$ and $\mathrm{T} 3$.

We applied robust statistical procedures (see 'Section 2'), which allowed us to retrieve several previously known ER- $\alpha$ target promoters (i.e. CTSD, BRCA, c-Myc, ADORA1, AGT, HSPB1, LCN2; O'Lone et al., 2004). With this method, 904 potential ER- $\alpha$ binding sites were identified in total (Supplemental Table S-I), some of which are common to recent genome-wide screenings for ER- $\alpha$ targets (Supplemental Table S-II). The 904 binding sites are equally distributed over all chromosomes (Table 1), excluding the Y chromosome, as the T47D line is derived from a woman. Only one site was found on chromosome $\mathrm{Y}$ and is not included in the list of 904 targets.

\subsection{ChIP-chip validation and target promoter features}

To validate the findings of the ChIP-chip, standard ChIP assays were performed using additional independent experiments (two or more) and ER- $\alpha$ binding was confirmed for a selection of 12 promoter regions (Fig. 1B). Enrichments were not seen for three non-target locations (PGR gene exons 4 and 6 and chromosome region $12 \mathrm{p} 13.3)$.

To demonstrate that ER- $\alpha$ binding to the promoter regions is functional, the effect on mRNA expression was studied with RT-PCR (Fig. 1B). The expression of most genes is induced by $17 \beta$-estradiol, with the exception of DKFZ p762E1312, which is down-regulated, and FANCM, which does not respond despite ER- $\alpha$ binding to its promoter (Fig. 1B). In addition, we evaluated the transcriptional response of six target genes for which ChIP reactions were not setup, CCNE2, IGF1-R, FBP-1, BCL2, MALL and CA2 (Supplemental Figure S-3). All genes, except $C A 2$, are induced by $17 \beta$-estradiol. MALL and $C A 2$ are induced by $\mathrm{OH}$-tamoxifen, whereas BCL2 and CCNE2 expression is reduced by $\mathrm{OH}$-tamoxifen.

Binding sites for ER- $\alpha$ are present both upstream and downstream of the transcription start site (TSS) and are evenly distributed along the promoter regions with respect to the distance from the TSS (results not shown). Seventy four percent of the 904 target promoters contain an estrogen response element (ERE; Fig. 1C), determined with the Genomatix MatInspector software.

\subsection{Selective recruitment of co-regulators determines the ER- $\alpha$ mediated transcription}

Both $17 \beta$-estradiol and $\mathrm{OH}$-tamoxifen can simultaneously upand down-regulate the transcription of different genes in the same cell. To verify whether differential co-regulator recruitment (i.e. co-activators versus co-repressors) accounts for these opposite transcriptional responses in the same cells, we performed ChIP with antibodies directed against ER- $\alpha$, co-activators p300, CBP and SRC1 or co-repressors SMRT and NCoR after exposing T47D cells for $50 \mathrm{~min}$ to $1 \mathrm{nM} 17 \beta$-estradiol or to $1 \mu \mathrm{M} \mathrm{OH}$-tamoxifen. These coregulators were selected because they are expressed in T47D cells (Supplemental Figure S-1) and all three co-activators are efficiently recruited at the promoter of TFF1 after $17 \beta$-estradiol induction (results not shown). It should be noted that we did not aim at identifying which specific co-regulator binds to one region, but rather whether co-activators or co-repressors are recruited. CBP/p300 are general mediators, which bridge the basal transcriptional machinery to the ER- $\alpha /$ co-activator complex, irrespective to which specific protein is present (SRC1, SRC2 or SRC3; Smith et al., 1996; Vo and Goodman, 2001). Therefore, in order to immunoprecipitate all DNA sequences interacting with co-activators simultaneously, we pooled the antibodies against p300, CBP and SRC-1. For the same reasons, we pooled co-repressor NCoR and SMRT antibodies.

The expression of TFF1, DDX-27, ZNF-228 and ZWINT is upregulated by $17 \beta$-estradiol and down-regulated by $\mathrm{OH}$-tamoxifen (Fig. 2), which correlates well with the recruitment of co-activators and co-repressors, respectively. In contrast, the expression of FLNA, SYMPK, KGFLP1 and BCL2L1 is induced by both $17 \beta$-estradiol and $\mathrm{OH}$-tamoxifen (Fig. 3). In these cases, predominant recruitment of co-activators is observed, although for some gene-promoters a non-significant recruitment of co-repressors can be seen as well (BCL2L1 after 17 $\beta$-estradiol treatment and FLNA after $\mathrm{OH}-$ tamoxifen treatment). Expression of DKFZ p762E1312 is suppressed by both $17 \beta$-estradiol and $\mathrm{OH}$-tamoxifen (Fig. $4 \mathrm{~A}$ ). In the presence of $17 \beta$-estradiol, ER- $\alpha$ recruits co-repressors only; however, in the presence of $\mathrm{OH}$-tamoxifen, co-activators are recruited as well (Fig. 4A). This could be explained by the fact that $\mathrm{OH}-$ tamoxifen induces the transcription of DKFZ p762E1312 at later 

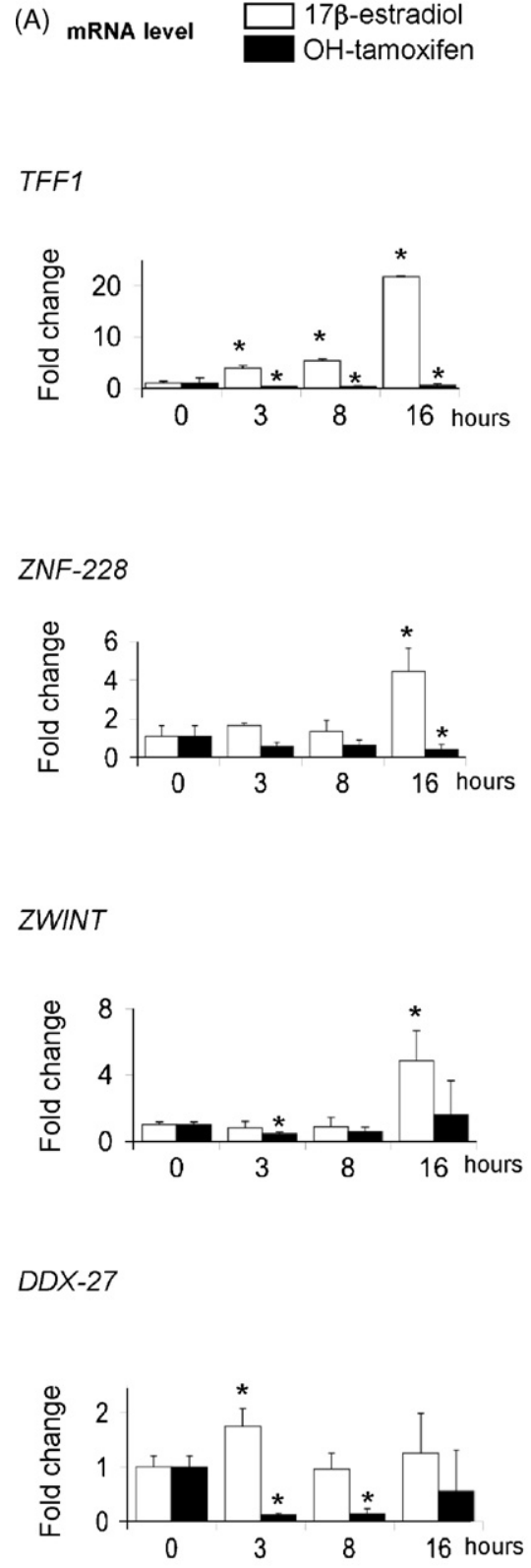

(B)

ChIP assay

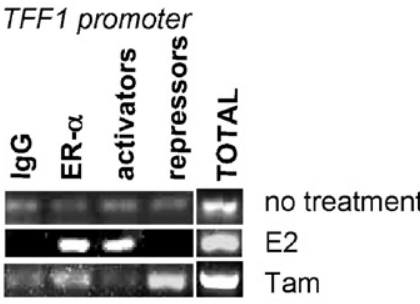

ZNF-228 promoter
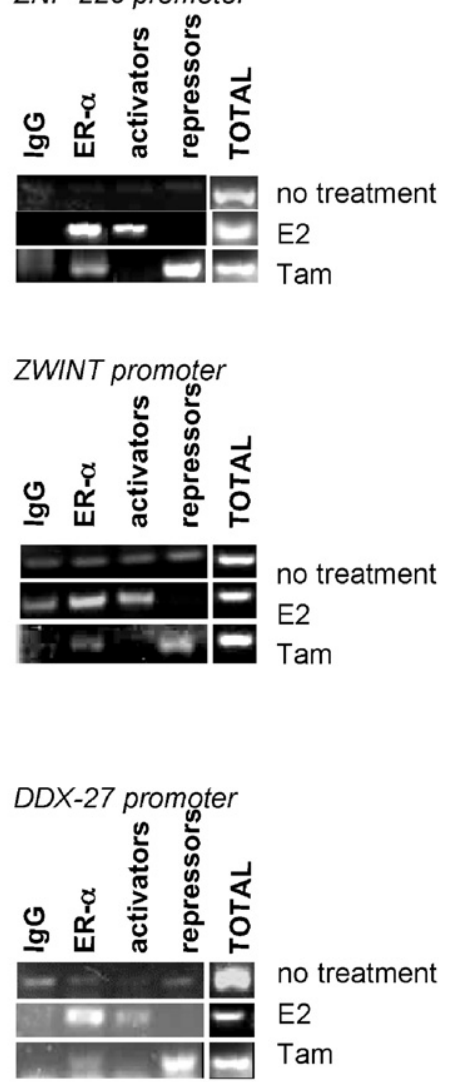

(C)

Quantification of chromatin enrichments in ChIP assay (semi-Q-PCR)
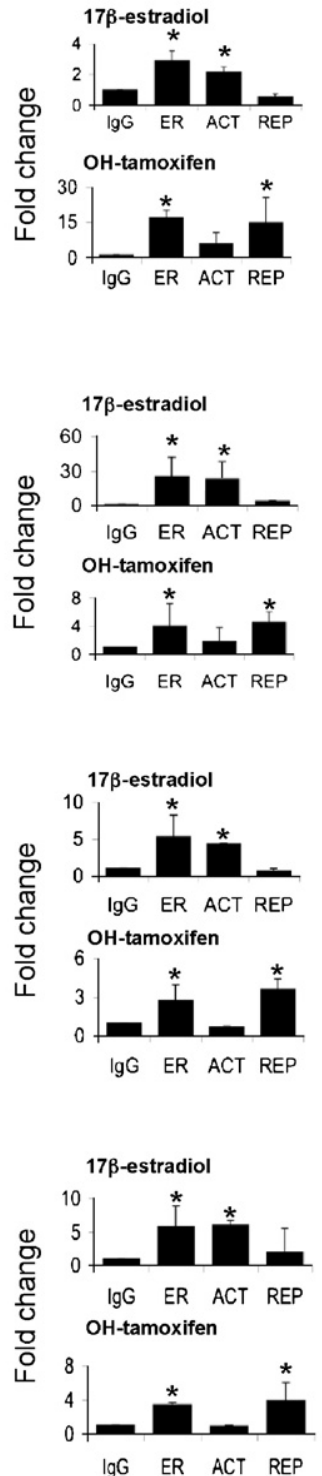

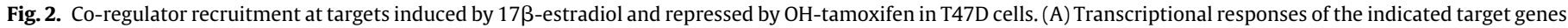

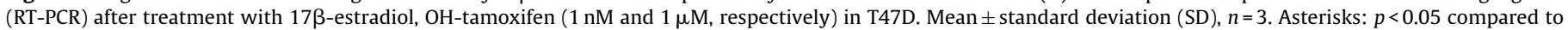

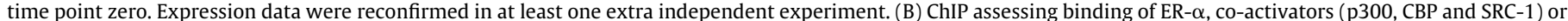

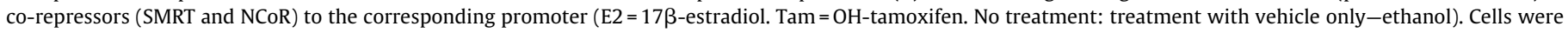

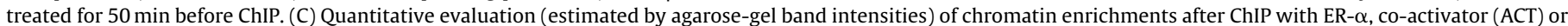

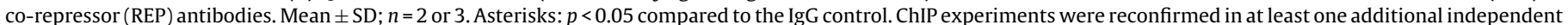
experiment. The ChIP negative control for these assays is shown in Fig. 4C.

time points (Supplemental Figure S-3). Also in case of the transcription up-regulation by $17 \beta$-estradiol of EPHA4 (Fig. 4B), ER- $\alpha$ recruits co-activators at the EPHA4 promoter. No recruitment of coregulators is observed for this gene in response to $\mathrm{OH}$-tamoxifen (Fig. 4B) and its transcription is not altered, even though ER- $\alpha$ binds to the promoter.

\subsection{Differential recruitment of co-regulators determines cell-specific transcriptional activities of $E R-\alpha$}

Next we examined whether co-activators and co-repressors are recruited to selected ER- $\alpha$ target genes in accordance with their opposite transcriptional responses to estrogens in T47D breast cells versus ECC1 endometrial cancer cells (ECC1 cells are ER$\alpha /$ co-regulator positive-Supplemental Figure S-1 and estrogen responsive-Supplemental Figure S-2). In ECC1 cells, KGFLP1, DDX27 and FLNA are induced by $17 \beta$-estradiol and OH-tamoxifen, whereas TFF1 is induced by $17 \beta$-estradiol only. ER- $\alpha$ preferentially recruits co-activators to up-regulate these genes (Fig. 5). In contrast, the transcriptional inhibitory effects of $17 \beta$-estradiol (for $B C L 2 L 1$ ) or OH-tamoxifen (for TFF1, BCL2L1 and EPHA4) are associated with the recruitment of co-repressors after ER- $\alpha$ binding (Fig. 5). Interestingly, OH-tamoxifen and $17 \beta$-estradiol reduce the expression of BCL2L1 in ECC1, but induce it in T47D cells (Figs. $5 \mathrm{~B}$ and 3 , respectively). In contrast, the expression of $D D X-27$ is induced in ECC1 and reduced in T47D cells by OH-tamoxifen (Figs. 


\section{Genes up-regulated by both $17 \beta$-estradiol and $\mathrm{OH}$-tamoxifen}

(A)

mRNA level $\square$ OH-tamoxifen

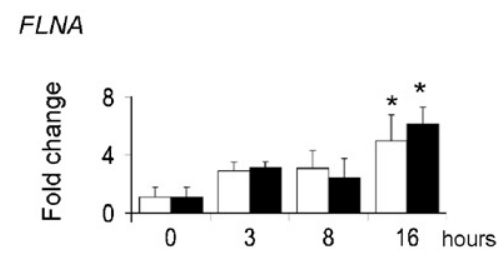

SYMPK

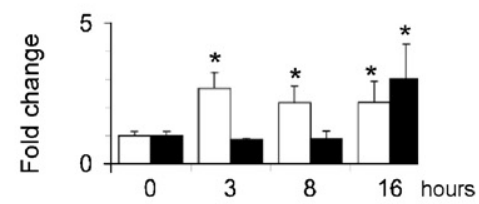

$B C L 2 L 1$

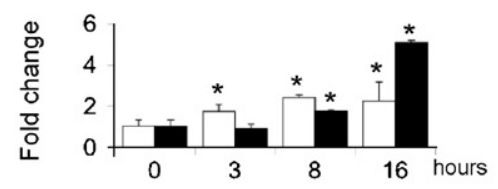

KGFLP1

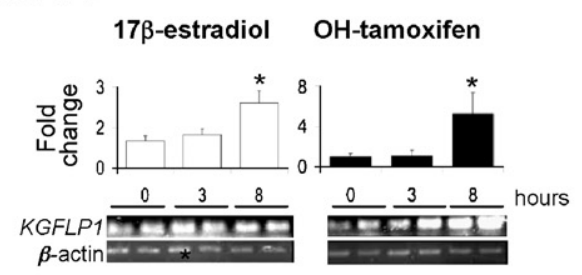

(B)

ChIP assay

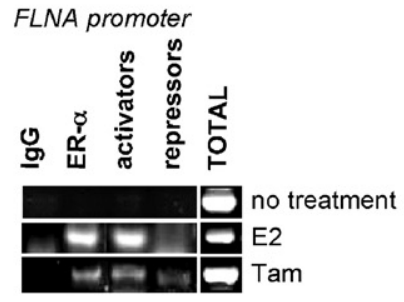

SYMPK promoter

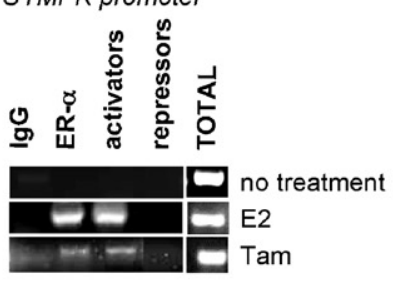

BCL2L1 promoter
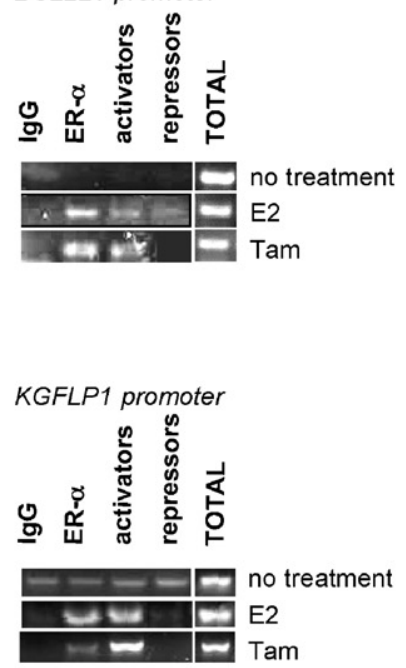

(C)

Quantification of chromatin enrichments in ChIP assay (semi-Q-PCR)
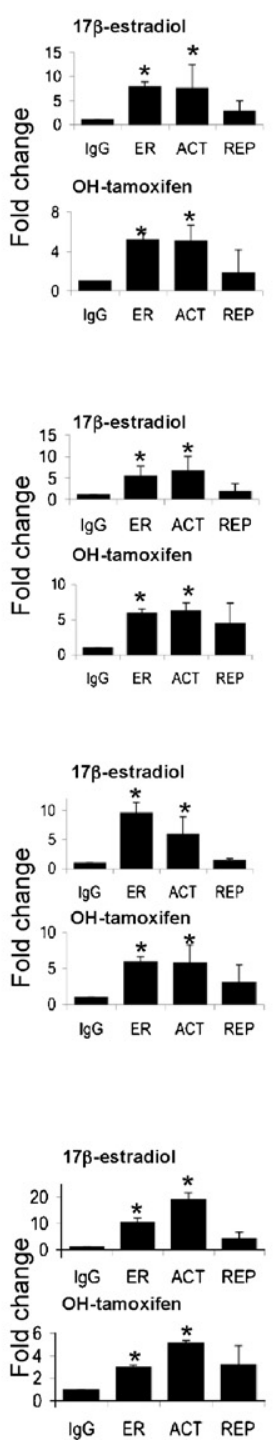

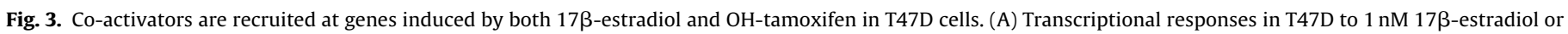

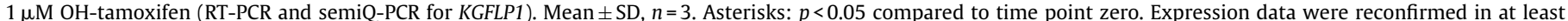

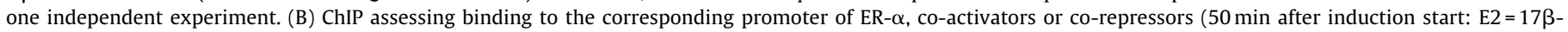

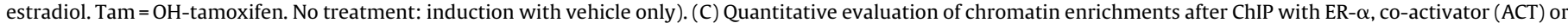

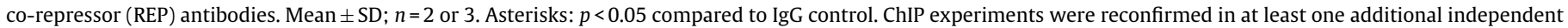
experiment (ChIP negative in Fig. 4C).

5B and 2, respectively). These opposite transcriptional effects are clearly related to the recruitment of different co-regulatory proteins in the two cell contexts: co-activators in case of induction and co-repressors in the case of inhibition of transcription. Analogue results are observed for EPHA4. This gene is induced by $17 \beta$-estradiol in T47D cells, under which condition ER- $\alpha$ recruits co-activators (Fig. 4B). However, EPHA4 is not responsive to $17 \beta-$ estradiol in ECC1 cells, and in this cell context, binding of ER- $\alpha$ to the corresponding promoter is not accompanied by further co-regulator recruitment (Fig. 5B). The opposite is observed with $\mathrm{OH}$-tamoxifen, which inhibits EPHA4 expression in ECC1 cells but has no effect T47D cells. In T47D cells, no co-regulators are recruited by ER- $\alpha$ (Fig. 4B), whereas in ECC- 1 cells, binding of ER- $\alpha$ is fol- lowed by recruitment of co-repressors (Fig. 5B). The recruitment of distinct co-regulators at the promoters of DDX-27 and BCL2L1 in T47D and ECC1 after induction with $\mathrm{OH}$-tamoxifen was confirmed by real-time PCR (Fig. 5D).

\subsection{Over-expression of SRC-1 and SMRT alters the response of target genes to $\mathrm{OH}$-tamoxifen}

If the regulation of the aforementioned genes is truly dependent on co-regulators, it should be expected that, as previously shown (Peterson et al., 2007; Smith et al., 1997), modification in the level of some of these proteins modifies the response of the target genes. Therefore, to confirm the association between up- or 
(A) Gene repressed by $17 \beta$-estradiol and repressed by $\mathrm{OH}$-tamoxifen

mRNA level $\square$ OH-tamoxifen

ChIP assay
Quantification of chromatin enrichments in ChIP assay (semi-Q-PCR)
DKFZp762E1312

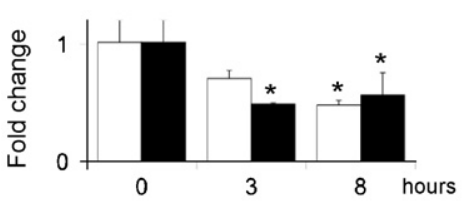

DKFZp762E1312 promoter

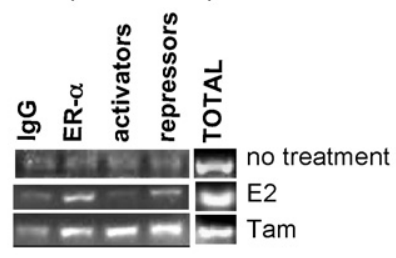

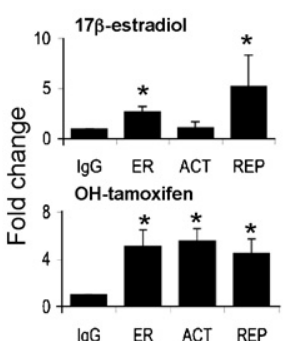

(B) Gene induced by $17 \beta$-estradiol and non-responsive to by $\mathrm{OH}$-tamoxifen

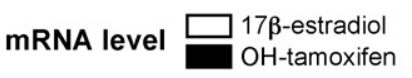

EPHA4

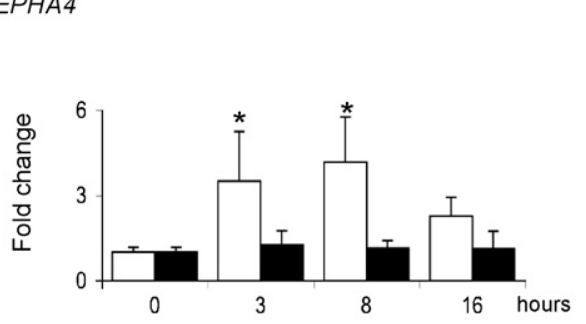

(C)
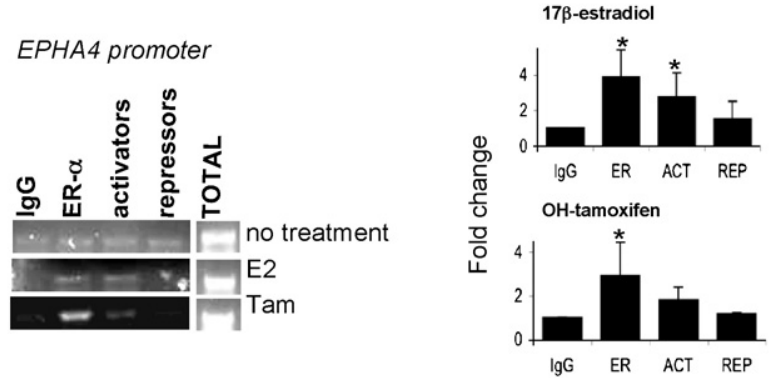

Quantification of chromatin enrichments in ChIP assay (semi-Q-PCR)
ChIP assay

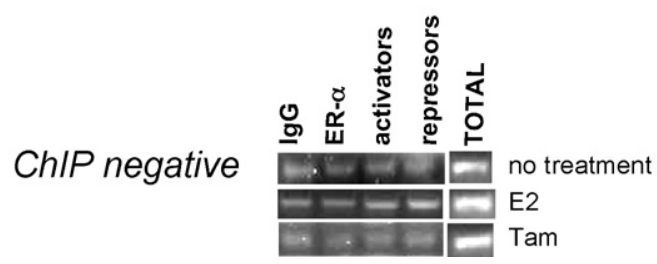

Fig. 4. Co-regulator recruitment by activated ER- $\alpha$ at DKFZ p762E1312 and EPHA4 in T47D cells. (A) On the left: transcriptional responses of the DKFZ p762E1312 gene (repressed by both $17 \beta$-estradiol- $1 \mathrm{nM}$ and $\mathrm{OH}$-tamoxifen $-1 \mu \mathrm{M}$ ) in T47D (RT-PCR). Mean \pm SD, $n=3$. Asterisks: $p<0.05$ versus time point zero. RNA data were reconfirmed in at least one extra independent experiment. Middle: ChIP assessing binding to the DKFZ p 762E1312 promoter of ER- $\alpha$, co-activators or co-repressors. ChIP was performed 50 min after induction start: $\mathrm{E} 2=17 \beta$-estradiol. Tam $=\mathrm{OH}$-tamoxifen. No treatment: vehicle only. Right: quantitative evaluation of chromatin enrichments after ChIP with ER- $\alpha$, co-activator (ACT) or co-repressor (REP) antibodies. Mean \pm SD. Asterisks: $p<0.05$ versus IgG control, $n=2$ or 3 . (B) EPHA4 gene is induced by $17 \beta$-estradiol ( $1 \mathrm{nM}$ ) but is not influenced by $1 \mu \mathrm{M}$ OH-tamoxifen (on the left; mean \pm SD, $n=3$. Asterisks: $p<0.05$ versus time point zero). RNA data were reconfirmed in at least one extra independent experiment. Middle and right: ChIP assay and quantitative evaluation of the ChIP experiments (mean \pm SD based on at least two independent experiments. Asterisks: $p<0.05$ versus IgG control). (C) ChIP negative control (cytogenetic location 12p13.3).

down-regulation and recruitment of co-activators or repressors, we over-expressed co-activator SRC-1 or co-repressor SMRT by transient transfections in T47D and ECC1 cells (Fig. 6A). To proof that these transfections had significant and measurable effects, we assessed the activity of the estrogen responsive construct ERE-TK-luciferase after co-transfection with SRC-1 or with SMRT. As expected, SRC-1 over-expression enhances the $17 \beta$-estradiolinduced luciferase activity, whereas SMRT reduces it (Fig. 6B). Moreover, to confirm the transfectability of T47D and ECC 1 cells we also measured GFP expression after transient transfection with a GFP expression plasmid (Supplemental Figure S-4).

Fig. 6C shows the effect of SRC-1 or SMRT over-expression on a number of identified target genes. In T47D cells, BCL2L1 transcription is normally up-regulated by OH-tamoxifen. Overexpression of the co-activator SRC-1 enhances this effect, whereas over-expression of the co-repressor SMRT changes OH-tamoxifen into an inhibitor of transcription (Fig. 6C). In ECC1, BCL2L1 is normally repressed by OH-tamoxifen, but over-expression of SRC-1 changes $\mathrm{OH}$-tamoxifen into an inducer of transcription.

With regard to the expression of EPHA4, over-expression of SRC1 in T47D cells turns OH-tamoxifen into an inducer of transcription, whereas this gene is unresponsive under normal conditions. In ECC1 cells, EPHA4 transcription is inhibited by $\mathrm{OH}$-tamoxifen and SRC-1 over-expression impairs this repressive activity. Also in case of the transcriptional activation of KGFLP1 in both T47D and ECC1 cells, SMRT over-expression is sufficient to revert (in T47D cells; 
(B) mRNA level and ChIP in ECC1 cells. These genes are regulated in an opposite direction in T47D cells

(A) mRNA level and ChIP in ECC1 cells. These genes are regulated in the same direction in T47D cells

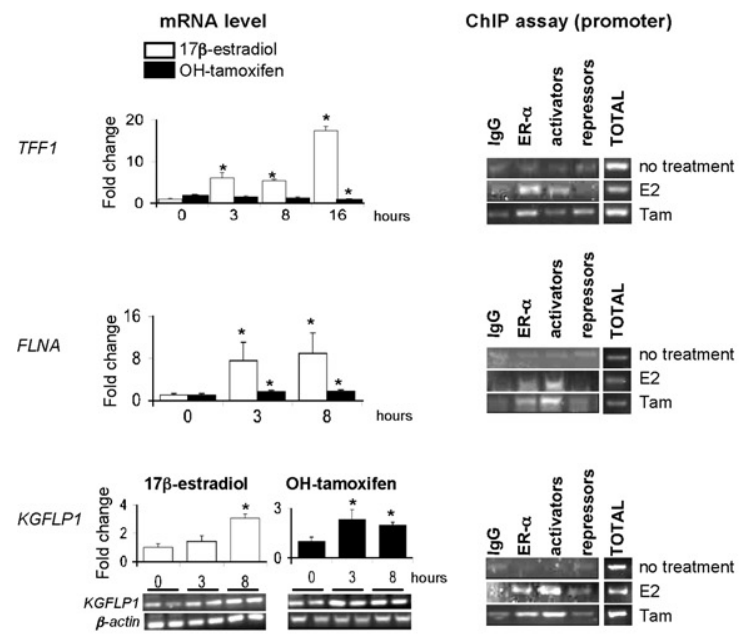

(D)

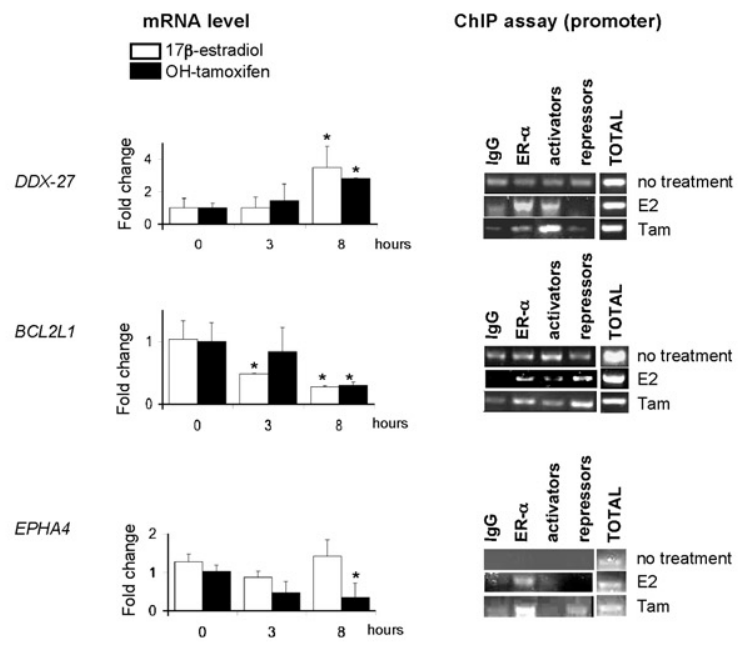

ChIP on DDX-27 and BCL2L1 (real time PCR) in T47D and ECC1 cells stimulated with $\mathrm{OH}$-tamoxifen

(C)

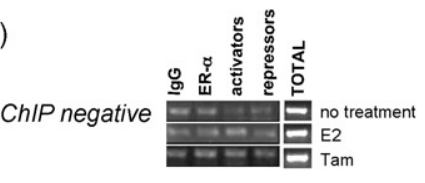

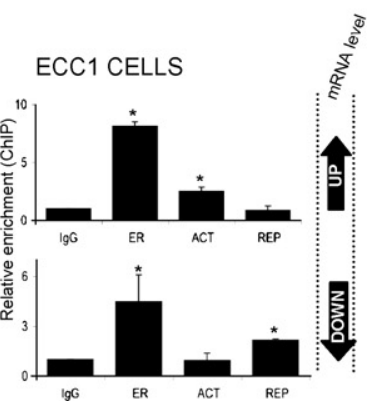

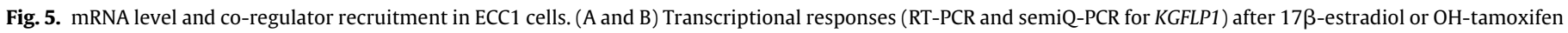

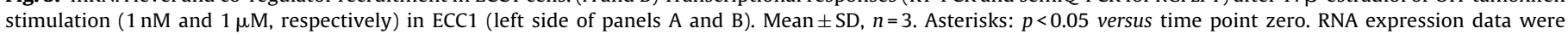

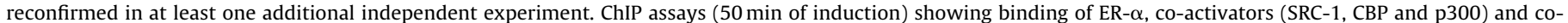

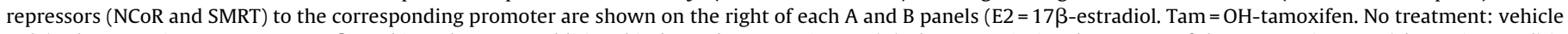

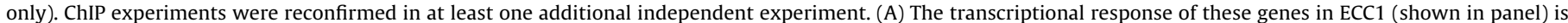

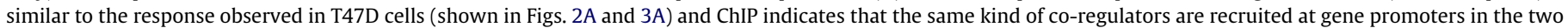

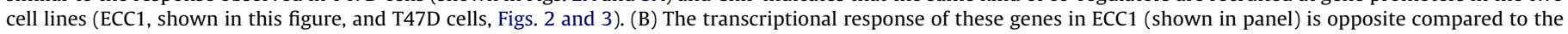

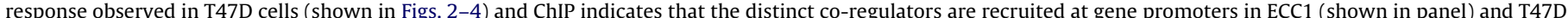

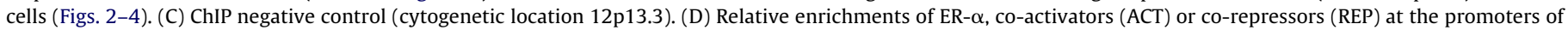

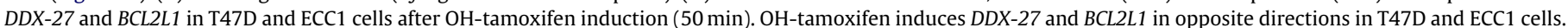

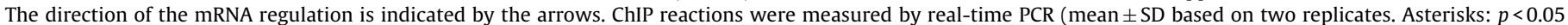
versus IgG control).

OH-tamoxifen becomes a repressor of transcription) or impair (in ECC1 cells; OH-tamoxifen does not change gene transcription) this response (Fig. 6C).

Transcription of $D D X-27$ is suppressed by OH-tamoxifen in T47D and induced in ECC1 cells. Over-expression of SRC-1 does not affect the inhibitory action of OH-tamoxifen in T47D, but over-expression of SMRT in ECC1 cells turns OH-tamoxifen into a repressor of transcription (Fig. 6C).

The response to OH-tamoxifen of other validated genes (TFF1, FLNA, SYMPK, DFFZ p762E1312, ZWINT and ZNF-228) and the responses to $17 \beta$-estradiol in general, were not significantly influenced by modifications of the level of SRC- 1 and SMRT (data not shown). This suggests that co-regulators, themselves or as a consequence of cell-specific post-translational modifications, are promoter-specific.

\section{Discussion}

The aim of the present study was to elucidate the role of coregulators in (i) the opposite transcriptional actions mediated by
ER- $\alpha$ on different target genes and (ii) the tissue specific actions of $\mathrm{OH}$-tamoxifen (and $17 \beta$-estradiol) in breast and endometrial cancer cells. To this end, we first identified ER- $\alpha$ target promoters genome-wide by ChIP-chip and subsequently we examined whether co-activators or co-repressors are recruited by activated ER- $\alpha$ at the promoters of a number of newly identified targets.

Though some past studies have focussed on the genome-wide identification of ER- $\alpha$ binding sites in breast cancer cell lines (Bourdeau et al., 2008; Carroll et al., 2005, 2006; Cheng et al., 2006; Jin et al., 2004; Kwon et al., 2007; Laganiere et al., 2005; Lin et al., 2004, 2007a,b), none have further considered the role of coregulators on the transcriptional regulation of these ER- $\alpha$ targets. Up to now, this knowledge has been generated by means of reporter gene assays (Peterson et al., 2007; Smith et al., 1997) or by studying a low number of estrogen responsive genes only (Shang and Brown, 2002; Shang et al., 2000).

In the present study, we identified 904 promoters targeted by ER- $\alpha$ using ChIP-chip. These results were validated by standard ChIP, by the estrogen responsiveness of the corresponding genes at 
(B) ERE-TK-Luciferase activity after SRC-1 or SMRT over expression

(A)

SRC-1 over expression SMRT over expression

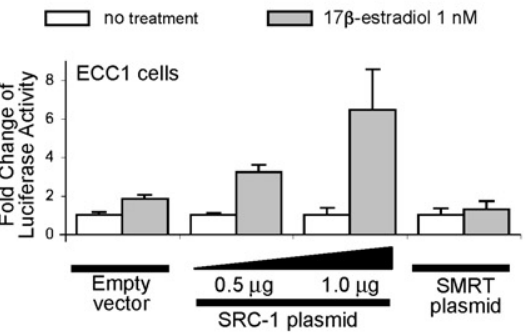

(C) Transcriptional response to OH-tamoxifen after SRC-1 or SMRT over expression

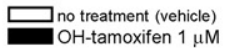

GENE:

$B C L 2 L 1$

$D D X-27$

EPHA4
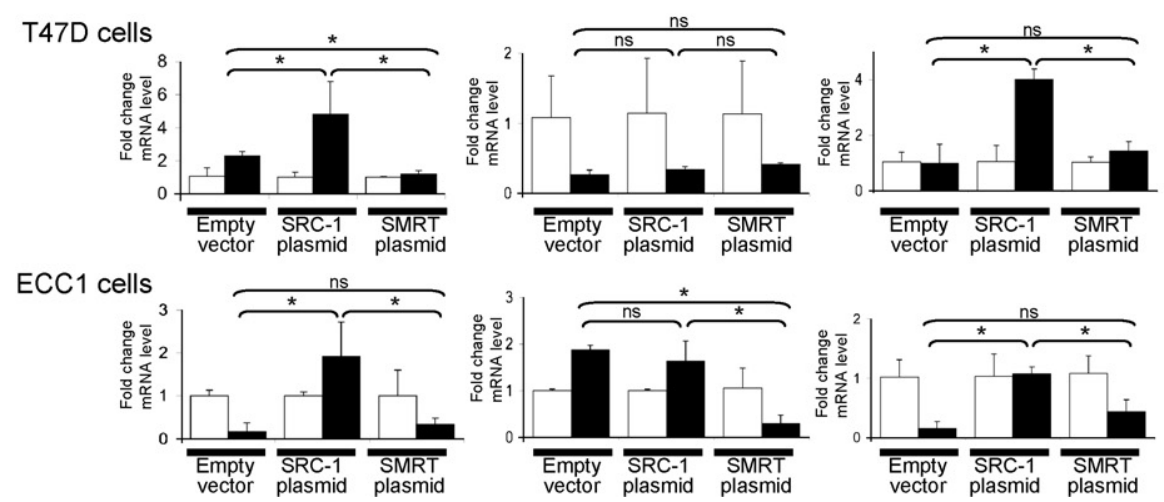

vector plasmid plasmid

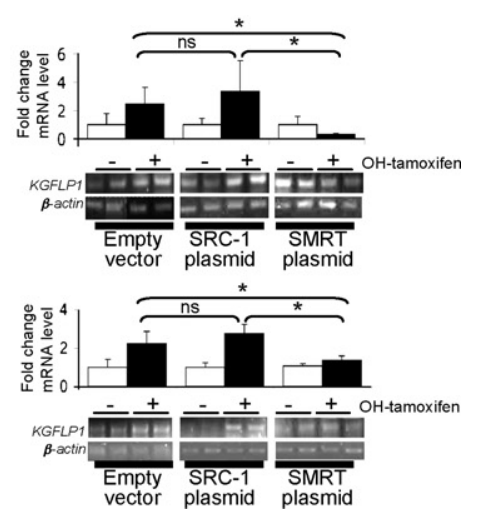

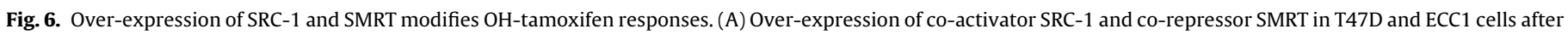

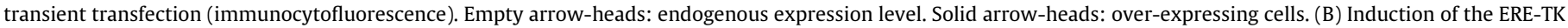

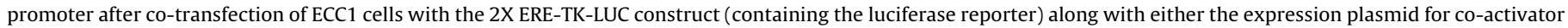

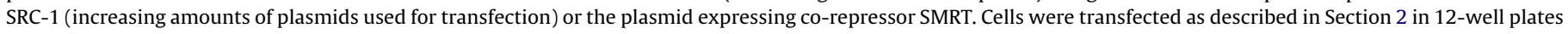

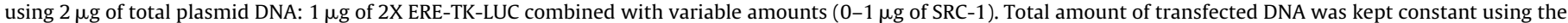

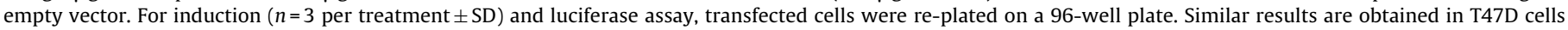

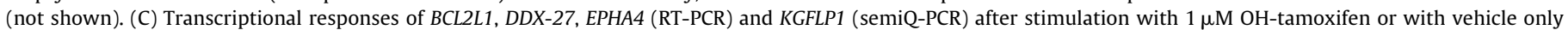

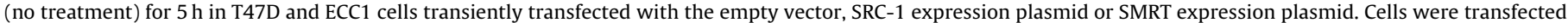

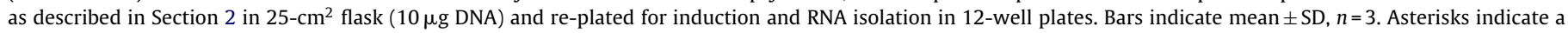
significant difference ( $p$-value $<0.05$ : $t$-test) between transfection experiments in the mRNA fold-change after OH-tamoxifen induction.

the mRNA level, and by the high prevalence of EREs among target promoters (Fig. 1).

\subsection{Co-regulator recruitment at target promoters determines gene- and cell-specific responses to ER- $\alpha$ ligands}

In line with previous studies (Shang and Brown, 2002; Shang et al., 2000; Stossi et al., 2006), activated ER- $\alpha$ binds to gene promoters, recruits co-activators or co-repressors, which determine the subsequent transcriptional up- or down-regulation, respectively (Figs. 2-5). In one cell type, all determinants of the ER- $\alpha$ action (like ligand concentration, level and activation of ER- $\alpha$ and coregulators) are identical, except for the promoter, which therefore must be responsible for the recruitment of different co-regulators. A number of studies have already shed light on the role of EREmotifs and additional cis-regulatory elements (AP1, Sp1, NFкB binding sites) in the cell- and ligand-specific regulation of ER- $\alpha$ and ER- $\beta$ (Klinge, 2001; Ramsey et al., 2004; Schultz et al., 2005). The main features of the genes analysed in the present study (EREs and binding sites for additional transcription factors) are given in Supplemental Table S-IV. Alternatively, it is possible that co-regulators are modified post-translationally in a cell-specific manner, resulting in altered interactions at gene promoters in the distinct cell contexts.
In one case only (DKFZ p762E1312), transcription repression by OH-tamoxifen was associated with recruitment of both corepressors and co-activators. We explained this effect with the ability of OH-tamoxifen to induce DKFZ p762E131 transcription at later time points. However, it should also be noted that the dynamics, the sequential and combinatorial assembly of co-activators and co-repressors at target promoters have not been addressed in the present investigation. Nevertheless, these events are important for the action of nuclear receptors (Metivier et al., 2003, 2004).

Differential co-regulator recruitment also explains the opposite transcriptional response observed at a number of target genes in response to OH-tamoxifen (DDX-27, BCL2L1 and EPHA4) or $17 \beta$ estradiol (BCL2L1 and EPHA4) in breast cancer (T47D; Figs. 2-4) and endometrial cancer cells (ECC1; Fig. 5). These results confirm a previous finding based on a number of known estrogen responsive genes (c-Myc, IGF-I, EBAG9 and CTSD; Shang and Brown, 2002). The present study extends this mechanism of action to potentially all ER- $\alpha$ target genes.

To further substantiate the association between transcriptional regulation and co-regulator recruitment, we over-expressed either co-activator SRC-1 or co-repressor SMRT. In a number of cases, the transcriptional response to OH-tamoxifen in T47D or ECC1 cells could be modified or inverted by over-expression of these co-regulators (BCL2L1, KGFLP1, EPHA4; Fig. 6). 
The transcription of other genes in response to $\mathrm{OH}$-tamoxifen was not influenced by SRC-1 or SMRT over-expression (TFF1, FLNA, SYMPK, DFFZ p762E1312, ZWINT and ZNF-228). In some cases, as observed for $D D X-27$, the inducing action of $\mathrm{OH}$-tamoxifen could be impaired in ECC1 after over-expression of SMRT, but the opposite inhibitory action of $\mathrm{OH}$-tamoxifen observed in T47D cells could not be changed by SRC-1 over-expression. As shown by others (Peterson et al., 2007; Yahata et al., 2001), each promoter interacts with a limited number of co-regulators only and therefore each coregulator modulates the expression of a limited number of genes. These events explain why co-regulators have distinct physiological functions (Kuang et al., 2005; Smith and O'Malley, 2004; Wang et al., 2009; Yu et al., 2007). In our case, it is entirely possible that SRC1 cannot be efficiently recruited at the $D D X-27$ promoter, whereas neither SRC-1 nor SMRT can be efficiently recruited at the promoter of other target genes, whose transcription was not influenced by these two co-regulators.

\section{Conclusions}

Complex events determine the action of ER- $\alpha$, including histone modifications (Krum et al., 2008), distal and proximal cis-regulatory elements (Carroll et al., 2006; Klinge, 2001; Ramsey et al., 2004; Schultz et al., 2005), ligand independent signalling and indirect DNA binding mediated by additional transcription factors. Our results suggest that, at least for direct ER- $\alpha$ targets, distinct co-regulator recruitment is one of the key modulators of hormonal response.

In case of important drugs like tamoxifen, ER- $\alpha$ is necessary but not sufficient to mediate its actions. The direction of the hormonal response is for a large part dependent on co-regulators. Aberrations in the functions mediated by these proteins may lead to endocrine related cancers, to innate and developed drug-resistance in breast tumours (Balmer et al., 2006; Conzen, 2008; Lonard et al., 2007) or to poor therapeutic response observed, for instance, in case of ovarian tumours (Perez-Gracia and Carrasco, 2002). Unravelling the expression and activation patterns of co-regulators in estrogen-dependent tumours may be the next step in predicting drug response and personalise endocrine therapies.

\section{Contributors}

This study was designed by AR, GD and PG; the experimental procedures were performed by AR with assistance from SK and BD; microarray, statistical and additional bioinformatics analyses were performed by MA and CE.

\section{Conflicts of interest}

The authors declare no conflict of interest.

\section{Acknowledgements}

The authors are grateful to Nard Kubben for optimising and providing us with the protocol for the linear-amplification of DNA prior to labelling and chip hybridisation. We are grateful to Prof Schuele, Prof O'Malley and Prof Evans for providing the expression and reporter plasmids we used. This study has been supported by internal funds of the Maastricht University Medical Centre.

\section{Appendix A. Supplementary data}

Supplementary data associated with this article can be found, in the online version, at doi:10.1016/j.mce.2009.08.008.

\section{References}

Balmer, N.N., Richer, J.K., Spoelstra, N.S., Torkko, K.C., Lyle, P.L., Singh, M., 2006. Steroid receptor coactivator AIB1 in endometrial carcinoma, hyperplasia and normal endometrium: correlation with clinicopathologic parameters and biomarkers. Mod. Pathol. 19, 1593-1605.

Benjamini, Y., Hochberg, Y., 1995. Controlling the false discovery rate: a practical and powerful approach to multiple testing. J. Roy. Statist. Soc. Ser. B 57, 289-300.

Bourdeau, V., Deschenes, J., Laperriere, D., Aid, M., White, J.H., Mader, S., 2008. Mechanisms of primary and secondary estrogen target gene regulation in breast cancer cells. Nucleic Acids Res. 36, 76-93.

Carroll, J.S., Brown, M., 2006. Estrogen receptor target gene: an evolving concept. Mol. Endocrinol. 20, 1707-1714.

Carroll, J.S., Liu, X.S., Brodsky, A.S., Li, W., Meyer, C.A., Szary, A.J., Eeckhoute, J., Shao, W., Hestermann, E.V., Geistlinger, T.R., Fox, E.A., Silver, P.A., Brown, M., 2005. Chromosome-wide mapping of estrogen receptor binding reveals long-range regulation requiring the forkhead protein FoxA1. Cell 122, 33-43.

Carroll, J.S., Meyer, C.A., Song, J., Li, W., Geistlinger, T.R., Eeckhoute, J., Brodsky, A.S., Keeton, E.K., Fertuck, K.C., Hall, G.F., Wang, Q., Bekiranov, S., Sementchenko, V., Fox, E.A., Silver, P.A., Gingeras, T.R., Liu, X.S., Brown, M., 2006. Genome-wide analysis of estrogen receptor binding sites. Nat. Genet. 38, 1289-1297.

Cartharius, K., Frech, K., Grote, K., Klocke, B., Haltmeier, M., Klingenhoff, A., Frisch, M., Bayerlein, M., Werner, T., 2005. MatInspector and beyond: promoter analysis based on transcription factor binding sites. Bioinformatics 21, 2933-2942.

Chen, J.D., Evans, R.M., 1995. A transcriptional co-repressor that interacts with nuclear hormone receptors. Nature $377,454-457$

Cheng, A.S., Jin, V.X., Fan, M., Smith, L.T., Liyanarachchi, S., Yan, P.S., Leu, Y.W., Chan, M.W., Plass, C., Nephew, K.P., Davuluri, R.V., Huang, T.H., 2006. Combinatorial analysis of transcription factor partners reveals recruitment of c-MYC to estrogen receptor-alpha responsive promoters. Mol. Cell 21, 393-404.

Conzen, S.D., 2008. Nuclear receptors and breast cancer. Mol. Endocrinol. 22, 2215-2228.

Gielen, S.C., Burger, C.W., Kuhne, L.C., Hanifi-Moghaddam, P., Blok, L.J., 2005. Analysis of estrogen agonism and antagonism of tamoxifen, raloxifene, and ICI182780 in endometrial cancer cells: a putative role for the epidermal growth factor receptor ligand amphiregulin. J. Soc. Gynecol. Invest. 12, e55-67.

Groothuis, P.G., Dassen, H.H., Romano, A., Punyadeera, C., 2007. Estrogen and the endometrium: lessons learned from gene expression profiling in rodents and human. Hum. Reprod. Update 13, 405-417.

Hodges, L.C., Cook, J.D., Lobenhofer, E.K., Li, L., Bennett, L., Bushel, P.R., Aldaz, C.M., Afshari, C.A., Walker, C.L., 2003. Tamoxifen functions as a molecular agonist inducing cell cycle-associated genes in breast cancer cells. Mol. Cancer Res. 1, 300-311.

Jin, V.X., Leu, Y.W., Liyanarachchi, S., Sun, H., Fan, M., Nephew, K.P., Huang, T.H., Davuluri, R.V., 2004. Identifying estrogen receptor alpha target genes using integrated computational genomics and chromatin immunoprecipitation microarray. Nucleic Acids Res. 32, 6627-6635.

Klinge, C.M., 2001. Estrogen receptor interaction with estrogen response elements. Nucleic Acids Res. 29, 2905-2919.

Krum, S.A., Miranda-Carboni, G.A., Lupien, M., Eeckhoute, J., Carroll, J.S., Brown, M., 2008. Unique ERalpha cistromes control cell type-specific gene regulation. Mol. Endocrinol. 22, 2393-2406.

Kuang, S.Q., Liao, L., Wang, S., Medina, D., O’Malley, B.W., Xu, J., 2005. Mice lacking the amplified in breast cancer 1 /steroid receptor coactivator-3 are resistant to chemical carcinogen-induced mammary tumorigenesis. Cancer Res. 65, 79938002.

Kwon, Y.S., Garcia-Bassets, I., Hutt, K.R., Cheng, C.S., Jin, M., Liu, D., Benner, C., Wang, D., Ye, Z., Bibikova, M., Fan, J.B., Duan, L., Glass, C.K., Rosenfeld, M.G., Fu, X.D., 2007. Sensitive ChIP-DSL technology reveals an extensive estrogen receptor alpha-binding program on human gene promoters. Proc. Natl. Acad. Sci. U.S.A. 104, 4852-4857.

Laganiere, J., Deblois, G., Lefebvre, C., Bataille, A.R., Robert, F., Giguere, V., 2005. From the Cover: location analysis of estrogen receptor alpha target promoters reveals that FOXA1 defines a domain of the estrogen response. Proc. Natl. Acad. Sci. U.S.A. 102, 11651-11656.

Lin, C.Y., Strom, A., Vega, V.B., Kong, S.L., Yeo, A.L., Thomsen, J.S., Chan, W.C., Doray, B., Bangarusamy, D.K., Ramasamy, A., Vergara, L.A., Tang, S., Chong, A., Bajic, V.B., Miller, L.D., Gustafsson, J.A., Liu, E.T., 2004. Discovery of estrogen receptor alpha target genes and response elements in breast tumor cells. Genome Biol. 5, R66.

Lin, C.Y., Vega, V.B., Thomsen, J.S., Zhang, T., Kong, S.L., Xie, M., Chiu, K.P., Lipovich, L., Barnett, D.H., Stossi, F., Yeo, A., George, J., Kuznetsov, V.A., Lee, Y.K., Charn, T.H., Palanisamy, N., Miller, L.D., Cheung, E., Katzenellenbogen, B.S., Ruan, Y., Bourque, G., Wei, C.L., Liu, E.T., 2007a. Whole-genome cartography of estrogen receptor alpha binding sites. PLoS Genet. 3, e87.

Lin, Z., Reierstad, S., Huang, C.C., Bulun, S.E., 2007b. Novel estrogen receptor-alpha binding sites and estradiol target genes identified by chromatin immunoprecipitation cloning in breast cancer. Cancer Res. 67, 5017-5024.

Lonard, D.M., Lanz, R.B., O'Malley, B.W., 2007. Nuclear receptor coregulators and human disease. Endocr. Rev. 28, 575-587.

Lonard, D.M., O'Malley, B.W., 2007. Nuclear receptor coregulators: judges, juries, and executioners of cellular regulation. Mol. Cell 27, 691-700.

Metivier, R., Penot, G., Carmouche, R.P., Hubner, M.R., Reid, G., Denger, S., Manu, D., Brand, H., Kos, M., Benes, V., Gannon, F., 2004. Transcriptional complexes engaged by apo-estrogen receptor-alpha isoforms have divergent outcomes. EMBO J. 23, 3653-3666. 
Metivier, R., Penot, G., Hubner, M.R., Reid, G., Brand, H., Kos, M., Gannon, F., 2003. Estrogen receptor-alpha directs ordered, cyclical, and combinatorial recruitment of cofactors on a natural target promoter. Cell 115, 751-763.

O'Lone, R., Frith, M.C., Karlsson, E.K., Hansen, U., 2004. Genomic targets of nuclear estrogen receptors. Mol. Endocrinol. 18, 1859-1875.

Oehler, M.K., Greschik, H., Fischer, D.-C., Tong, X.-W., Schuele, S., Kieback D.G., 2004. Somatic mutations affecting the function of the human estrogen receptor alpha(hER-alpha) in adenomyosis uteri. Mol. Hum. Reprod. 10, 853-860.

Perez-Gracia, J.L., Carrasco, E.M., 2002. Tamoxifen therapy for ovarian cancer in the adjuvant and advanced settings: systematic review of the literature and implications for future research. Gynecol. Oncol. 84, 201-209.

Peterson, T.J., Karmakar, S., Pace, M.C., Gao, T., Smith, C.L., 2007. The silencing mediator of retinoic acid and thyroid hormone receptor (SMRT) corepressor is required for full estrogen receptor alpha transcriptional activity. Mol. Cell. Biol. 27, 5933-5948.

Ramsey, T.L., Risinger, K.E., Jernigan, S.C., Mattingly, K.A., Klinge, C.M., 2004 Estrogen receptor $\beta$ isoforms exhibit differences in ligand-activated transcriptional activity in an estrogen response element sequence-dependent manner. Endocronology 145, 149-160.

Riggs, B.L., Hartmann, L.C., 2003. Selective estrogen-receptor modulatorsmechanisms of action and application to clinical practice. N Engl. J. Med. 348, 618-629.

Romano, A., Delvoux, B., Fischer, D.C., Groothuis, P., 2007. The PROGINS polymorphism of the human progesterone receptor diminishes the response to progesterone. J. Mol. Endocrinol. 38, 331-350.

Schultz, J.R., Petz, L.N., Nardulli, A.M., 2005. Cell- and ligand-specific regulation of promoters containing activator protein-1 and Sp1 sites by estrogen receptors $\alpha$ and $\beta$. J. Biol. Chem. 280, 347-354.
Shang, Y., 2006. Molecular mechanisms of oestrogen and SERMs in endometrial carcinogenesis. Nat. Rev. Cancer 6, 360-368.

Shang, Y., Brown, M., 2002. Molecular determinants for the tissue specificity of SERMs. Science 295, 2465-2468.

Shang, Y., Hu, X., DiRenzo, J., Lazar, M.A., Brown, M., 2000. Cofactor dynamics and sufficiency in estrogen receptor-regulated transcription. Cell 103, 843-852.

Smith, C.L., Nawaz, Z.B., O'Malley, W., 1997. Coactivator and corepressors regulation of the agonist/antagonist activity of the mixed antiestrogen, 4hydroxytamoxifen. Mol. Endocrinol. 11, 657-666.

Smith, C.L., O'Malley, B.W., 2004. Coregulator function: a key to understanding tissue specificity of selective receptor modulators. Endocr. Rev. 25, 45-71.

Smith, C.L., Onate, S.A., Tsai, M.J., O'Malley, B.W., 1996. CREB binding protein acts synergistically with steroid receptor coactivator-1 to enhance steroid receptordependent transcription. Proc. Natl. Acad. Sci. U.S.A. 93, 8884-8888.

Stossi, F., Likhite, V.S., Katzenellenbogen, J.A., Katzenellenbogen, B.S., 2006. Estrogenoccupied estrogen receptor represses cyclin G2 gene expression and recruits a repressor complex at the cyclin G2 promoter. J. Biol. Chem. 281, 16272-16278.

Vo, N., Goodman, R.H., 2001. CREB-binding protein and p300 in transcriptional regulation. J. Biol. Chem. 276, 13505-13508.

Wang, S., Yuan, Y., Liao, L., Kuang, S.Q., Tien, J.C., O'Malley, B.W., Xu, J., 2009. Disruption of the SRC-1 gene in mice suppresses breast cancer metastasis without affecting primary tumor formation. Proc. Natl. Acad. Sci. U.S.A. 106, 151-156.

Yahata, T., Shao, W., Endoh, H., Hur, J., Coser, K.R., Sun, H., Ueda, Y., Kato, S., Isselbacher, K.J., Brown, M., Shioda, T., 2001. Selective coactivation of estrogendependent transcription by CITED1 CBP/p300-binding protein. Genes Dev. 15, 2598-2612.

Yu, C., York, B., Wang, S., Feng, Q., Xu, J., O'Malley, B.W., 2007. An essential function of the SRC-3 coactivator in suppression of cytokine mRNA translation and inflammatory response. Mol. Cell 25, 765-778. 